\title{
PENERAPAN PENDIDIKAN KARAKTER DALAM MENGURANGI PERILAKU MENYIMPANG SISWA DI SMA NEGERI 2 LHOKSEUMAWE
}

\author{
A. Marliah, M. Nazaruddin ${ }^{1)}$, M. Akmal \\ ${ }^{1}$ Program Magister Sosiologi FISIP Universitas Malikussaleh, muh.nazaruddin@unimal.ac.id
}

\section{ABSTRACT}

This study focuses on two discussions. First, to describe the application of character education at SMA Negeri 2 Lhokseumawe. Second, to describe the obstacles in the application of character education so that it is not effective in overcoming student deviant behavior. By using a qualitative approach, this study comes to an understanding that the implementation of character education in SMA Negeri 2 Lhokseumawe is carried out through several strategies, including: a). providing outreach to teachers; b). preparation of syllabus and lesson plans based on character education; c). integrating and applying values in the teaching and learning process in the classroom; d) creating a school culture; e) habituation; and f) teacher exemplary. The implementation of character education in order to reduce students' deviant behavior has not been optimal because it faces a number of obstacles, such as a) minimal family contribution; $b$ ) inconsistency of values and norms at school and outside school; and c) teachers' difficulties in adapting to curriculum changes. In addition, the definition of deviant behavior and social dysfunction has so far only relied on "blaming deviant individual behavior", but ignores problems at the school structure level that can lead students to deviant behavior and anomie states.

Keywords: Character Education, School, Conformity, Deviant Behavior, Anomie

\begin{abstract}
ABSTRAK
Studi ini berfokus pada dua hal. Pertama melihat penerapan pendidikan karakter di SMA Negeri 2 Lhokseumawe. Kedua, menggambarkan hambatan dalam penerapan pendidikan karakter sehingga tidak efektif dalam mengatasi perilaku menyimpang siswa. Dengan menggunakan pendekatan kualitatif, studi ini sampai pada pemahaman bahwa penerapan pendidikan karakter di SMA Negeri 2 Lhokseumawe dilakukan melalui beberapa strategi, diantaranya: a). pemberian sosialisasi kepada guru; b). penyusunan Silabus dan RPP yang berbasis pendidikan karakter; c). pengintegrasian dan penerapan nilai-nilai dalam proses belajar mengajar di kelas; d) penciptaan budaya sekolah; e) pembiasaan; dan f) keteladanan guru. Penerapan pendidikan karakter dalam rangka mengurangi perilaku menyimpang siswa belum berjalan optimal karena menghadapi sejumlah kendala, seperti a) minimnya kontribusi keluarga; b) inkonsistensi nilai dan norma di sekolah dan di luar sekolah; dan c) kesulitan guru beradaptasi dengan perubahan kurikulum. Selain itu, pendefinisian perilaku menyimpang dan disfungsi sosial selama ini hanya bertumpu pada "menyalahkan perilaku individu yang menyimpang", tetapi mengabaikan masalah pada level struktur sekolah yang dapat mendorong siswa ke arah perilaku menyimpang dan keadaan anomie.
\end{abstract}

Kata Kunci: Pendidikan Karakter, Sekolah, Konformitas, Perilaku Menyimpang, Anomie 


\section{PENDAHULUAN}

Fenomena dekadensi moral di Aceh menjadi sorotan tajam selama satu dekade ini. Berbagai media massa baik cetak maupun elektronik memberitakan tentang persoalan kenakalan remaja yang sangat meresahkan masyarakat. Pada lingkup Kota Lhokseumawe saja, tanggal 15 Februari 2013 silam koran Serambi Indonesia merilis data survey Dinas Kesehatan Provinsi Aceh dimana 70 persen pelajar di Kota Lhokseumawe terlibat pergaulan bebas sehingga menduduki klasemen pertama di Aceh dimana perilaku seks pra-nikah dan praktik mesum dilakukan oleh pelajar di wilayah ini (www.aceh.tribunnews.com). Baru sekitar tiga tahun berlalu, masyarakat kembali dibuat resah ketika terkuak fenomena LGBT (lesbian, gay, biseksual, transeksual) yang mulai marak di Kota Lhokseumawe. Pelakunya kebanyakan kaum remaja yang biasa mangkal di tempat rekreasi Jl. Lingkar Waduk Lhokseumawe (www.harianrakyataceh.com). Pergaulan bebas ternyata berjalan beriringan dengan meningkatnya kasus HIV/AIDS di Tanah Pase dimana pada tahun 2019 sudah mencapai 82 kasus (www.aceh.tribunnews.com).

Berbagai kasus kenakalan remaja yang lain juga tidak kalah mengkhawatirkan seperti tawuran antara pemuda dan warga di Terminal Labi-Labi Desa Keude Aceh yang dipicu oleh suara petasan yang terjadi pada tahun 2016 (www.aceh.tribunnews.com), penangkapan 4 remaja yang terlibat dalam peredaran sabu-sabu pada tahun 2017 (www.kanalaceh.com), pembubaran ratusan remaja yang terlibat balap liar di sepanjang Jl. Len Pipa pada tahun 2020 (www.acehportal.com), dan berbagai kasus lainnya. Ibarat fenomena gunung es, kasus-kasus yang sudah disebutkan ini hanyalah sebagian kecil yang mencuat ke permukaan.

Maraknya fenomena dekandensi moral disinyalir karena pengaruh globalisasi yang mengintrodusir budaya dari luar. Pelajar yang masih dalam masa usia transisi adalah sasaran rentan. Seiring dengan perkembangan teknologi informasi yang semakin pesat, pemanfaatannya yang salah membuat moral para pelajar mengalami kemerosotan dengan sinyal pengabaian terhadap nilai-nilai dan norma yang sudah lama hidup di tengah masyarakat Aceh. Sejalan dengan itu, gaya hidup para remaja saat ini mulai meniru budaya luar yang ditandai dengan perubahaan pada mode rambut, cara berpakaian, cara berbicara, dan budaya-budaya lain yang tidak sesuai dengan identitas masyarakat Aceh.

Mengantisipasi fenomena perilaku menyimpang tersebut, pemerintah (baik pusat maupun daerah) telah melakukan berbagai upaya mulai dari penerbitan peraturan-peraturan yang mengatur tata kehidupan dan moral masyarakat hingga penertiban atau penegakan hukum. Dalam ruang lingkup wilayah Aceh, pelaksanaan Syariat Islam tidak mengendur sejak diberlakukan mulai tahun 2006. Namun upaya ini ternyata belum membuahkan hasil yang maksimal. Sebagai kebijakan 
alternatif dalam mengurangi perilaku menyimpang pemerintah kemudian mencoba melakukan upaya lain yang lebih menitikberatkan sisi preventif, yaitu integrasi pendidikan karakter di sekolahsekolah yang wajib diterapkan dalam setiap pembelajaran dan mata pelajaran. Kementerian Pendidikan Nasional (2011) mendukung ini dimana penilaian siswa yang tadinya hanya dilakukan pada aspek kognitif, kini juga harus mencakup aspek afektif dan psikomotorik yang akhirnya dapat membentuk perilaku siswa yang berakhlak mulia yang sejalan dengan substansi Undang-Undang Sisdiknas. Dalam hal ini, fungsi sekolah tidak hanya sebagai "pabrik" yang menghasilkan lulusan yang cakap pengetahuan dan keterampilannya di tengah masyarakat, tetapi juga menghasilkan lulusan yang mampu menjaga hubungan baik dengan Tuhan dan sesama manusia.

Kurikulum pendidikan karakter sudah diimplementasikan selama beberapa tahun di SMA Negeri 2 Lhokseumawe. Namun terdapat kesenjangan antara harapan dengan kenyataan di lapangan. Berdasarkan hasil observasi dalam ruang lingkup sekolah saja masih ditemukan siswasiswa yang menyimpang seperti terlambat datang ke sekolah, membolos di saat jam pelajaran berlangsung, merokok di dalam toilet, mengeluarkan kata-kata kasar dalam berbicara, berselisih dengan teman, membuang sampah sembarangan, tidak mengucapkan salam jika bertemu sesama, menyontek saat ujian, dan berbagai pelanggaran tata tertib sekolah lainnya. Bahkan dalam laporan guru Bimbingan dan Konseling, beberapa siswa terlibat dalam kasus kenakalan di luar sekolah seperti balapan liar, vandalisme (pengrusakan fasilitas umum), Sementara dari laporan sebagian besar guru, perilaku menyontek paling sering dilakukan siswa di SMA Negeri 2 Lhokseumawe yang dikhawatirkan oleh guru akan menghasilkan "siswa yang pintar tapi tidak benar". Sebagaimana telah umum diketahui, fenomena ini disinyalir sebagai salah satu masalah klasik bangsa Indonesia yang menyebabkan sulitnya bangsa kita maju. Berdasarkan latar belakang masalah yang telah dijabarkan penulis merumuskan masalah tersebut dalam bentuk pertanyaan penelitian sebagai berikut: 1) Bagaimana penerapan pendidikan karakter dalam proses pembelajaran di SMA Negeri 2 Lhokseumawe? 2) Apa saja hambatan yang dihadapi dalam penerapan pendidikan karakter dalam rangka mengatasi perilaku menyimpang siswa di SMA Negeri 2 Lhokseumawe?

Selama ini, kajian tentang pendidikan karakter lebih sering difokuskan pada lingkup studi ilmu pendidikan terapan. Hal ini karena, sepertinya, jumlah mahasiswa yang kuliah di Fakultas Keguruan dan Ilmu Pendidikan di Indonesia relatif lebih banyak daripada mahasiswa yang kuliah di Program Studi Sosiologi. Dengan kelebihan tersebut, studi tentang tema pendidikan karakter lebih didominasi oleh para sarjana pendidikan. Hal itu seperti beberapa studi yang dilakukan oleh Citra (2012), Maunah (2015), Hendriana \& Jacobus (2016), Setiawati (2017). Sementara kajian 
tentang pendidikan karakter dalam lingkup studi sosiologi dilakukan oleh Xena (2019) dengan menggunakan perspektif Bergerian. Adapun studi yang akan peneliti lakukan mengangkat masalah penerapan pendidikan karakter di sekolah menengah yang berfokus pada upaya mengurangi perilaku menyimpang pada siswa. Sejauh ini, kajian tentang penerapan pendidikan karakter di sekolah dalam analisis sosiologi masih sangat terbatas, khususnya yang berkaitan dengan isu konformitas dan penyimpangan sosial. Hal itu membuat penelitian ini belum usang untuk dilakukan. Berbeda dengan penelitian Xena yang menggunakan perspektif Bergerian, penelitian ini berangkat dari perspektif sosiologis Merton dalam memahami permasalahan dan hambatan dalam penerapan pendidikan karakter di sekolah.

\section{Konformitas dan Perilaku Menyimpang}

Perspektif struktural fungsional digunakan sebagai titik tolak dalam memahami permasalahan penelitian ini. Perspektif struktural fungsional berakar dari pemikiran sosiolog klasik yang bernama Emilie Durkheim. Ia mengembangkan gagasan tentang fakta sosial (Sunarto, 2004; Ritzer \& Goodman, 2011) yang dapat dipahami sebagai norma-norma yang mengikat masyarakat. Dalam perkembangan sosiologi di kemudian hari muncul tokoh lain yang bernama Talcott Parsons. Menurut Parsons masyarakat memiliki skema AGIL (Adaptation, Goal attainment, Integration, and Latency) sehingga mampu berfungsi dan beradaptasi terhadap berbagai masalah yang dijumpai (Juwita et. al., 2020). Dijelaskan lebih lanjut oleh Parsons dalam Upe (2010), oleh karena masyarakat diatur oleh nilai dan norma yang telah mapan, sistem masyarakat cenderung stabil dan harmonis.

Kontradiktif dengan Parsons, Merton berpendapat bahwa komponen-komponen sistem sosial tidak jarang berada dalam hubungan yang bersifat konflik. Jadi selalu ada konsekuensi disfungsional dalam setiap sistem sosial (Ritzer \& Goodman, 2011). Artinya, penyimpangan (deviasi) selalu ada di dalam setiap sistem sosial. Kenakalan siswa pada penelitian ini tergolong sebagai penyimpangan karena tindakan tersebut tidak sesuai dengan aturan atau nilai-nilai yang berlaku di sekolah dan lingkungan masyarakat. Meskipun keberadaan aturan di dalam masyarakat bersifat fungsional, beberapa kelompok justru memaknainya sebagai belenggu aktivitas (Risdawati, 2014). Jadi ketidakpatuhan terhadap hukum pada sebagian kelompok dipicu oleh adanya tekanan spesifik sehingga mereka lebih cenderung berperilaku menyimpang ketimbang berperilaku konform (Setiadi \& Kolip, 2011).

Penyimpangan menurut Merton dalam Mulyadi (2009), dapat dibedah dari dua unsur yaitu

unsur kultur dan unsur struktur. Kultur menghasilkan goal, sedangkan struktur menghasilkan 26 | Jurnal Ilmu Sosial dan Ilmu Politik Malikussaleh (JSPM) Volume 1 Nomor 1 Periode Januari-Juni 2020 
means. Ketidakharmonisan kedua unsur tersebut mendorong ke arah anomie, dan dengan demikian ke arah perilaku menyimpang (Sidi, 2014). Erianjoni (2015) menilai terjadinya pemilihan jalan alternatif yang dianggap menyimpang didorong oleh tidak terdapatnya keselarasan antara tujuan budaya dengan kesempatan yang tersedia dalam mewujudkan tujuan tersebut. Senada dengan opini tersebut, Narwoko \& Suyanto (2007) lebih jauh menafsirkan bahwa anomie terjadi karena ada banyak sistem nilai dan struktur budaya yang saling bertentangan di dalam masyarakat. Ketiadaan standar nilai yang ajeg atau pasti membuat masyarakat tidak memiliki kepatuhan atau bertindak sesuai dengan standarnya masing-masing.

Merton dalam Sunarto (2004) mengidentifikasi lima cara adaptasi individu dalam menghadapi situasi tertentu dimana empat diantaranya dapat dikategorikan sebagai perilaku menyimpang dan hanya satu cara adaptasi yang dapat dikatakan sebagai perilaku tidak menyimpang, sebagaimana gambaran di bawah ini:

Tabel 1. Cara Adaptasi Individu terhadap Situasi Sosial

\begin{tabular}{|l|c|c|}
\hline \multicolumn{1}{|c|}{ Cara Adaptasi } & Tujuan Budaya & Cara yang Diinstitusionalisasikan \\
\hline I. Conformity & + & + \\
\hline II. Innovation & + & - \\
\hline III. Ritualism & - & + \\
\hline IV. Retreatism & - & - \\
\hline V. Rebellion & \pm & \pm \\
\hline
\end{tabular}

Sumber: Sunarto, 2004: 180.

Menurut Durkheim, pemuda dipersiapkan masuk ke dalam masyarakat melalui pendidikan. Sekolah pada umumnya memperkenalkan kepada siswa nilai dan norma masyarakat. aturan-aturan sekolah pun biasanya searah dengan nilai dan norma tersebut (Salmiah, 2017: 99). Jadi sekolah dapat dilihat sebagai agen sosialisasi (Sunarto, 2004). Selain itu, sekolah juga bisa dipandang sebagai alat kontrol sosial yang bersifat preventif dan korektif (Tandi, 2019). Sistem pengendalian sosial ini sudah melembaga di dalam masyarakat (Sunarto, 2004). Perilaku menyimpang dikelola melalui proses pembimbingan tentang nilai dan norma (Herabudin, 2015). Di dalam institusi pendidikan, karakter siswa sengaja dibangun ke arah yang positif. Karakter itu sendiri dapat didefinisikan sebagai tabiat, perangai, dan sifat-sifat seseorang yang membedakan seseorang dengan yang lain (Badudu dalam Bahri, 2015: 61). Karakter yang dibangun oleh sekolah dengan sengaja mengarah kepada karakter yang konform dengan nilai dan norma masyarakat.

27 | Jurnal Ilmu Sosial dan Ilmu Politik Malikussaleh (JSPM) Volume 1 Nomor 1 Periode Januari-Juni 2020 


\section{METODE PENELITIAN}

Penelitian ini menggunakan pendekatan kualitatif dengan maksud menggali pemahaman dan penemuan (Moleong, 2010). Penggunaan metode kualitatif dalam penelitian ini dirasa sudah tepat karena hendak melihat penerapan pendidikan karakter di sekolah melalui pembelajaran dalam upaya mengatasi perilaku menyimpang siswa serta melihat sejauh mana keefektifan dari penerapan pendidikan karakter tersebut. Adapun temuan penelitian ini akan dipaparkan secara deskriptif. Penelitian ini dilakukan di SMA Negeri 2 Lhokseumawe. Penentuan lokasi penelitian didasarkan atas pertimbangan bahwa peneliti sudah sangat mengenal lokasi penelitian beserta fenomena yang sering terjadi di sekolah tersebut sehingga bias data atau tingkat keragu-raguan data dapat dipastikan kecil. Selain itu, tingkat kepercayaan responden terhadap peneliti sudah cukup baik karena saling mengenal dalam jangka waktu lama. Alasan lainnya yaitu karena SMA Negeri 2 Lhokseumawe pada saat ini sangat giat dalam penerapan program pendidikan karakter. Hal ini tercermin pada visi, misi, tujuan, dan strategi SMA Negeri 2 Lhokseumawe. Penelitian dilaksanakan dalam jangka waktu 5 bulan terhitung mulai bulan November 2019 sampai dengan bulan Maret 2020. Sumber data terdiri atas data primer dan data sekunder. Instrumen pengumpulan data terdiri atas wawancara mendalam, pengamatan, dan dokumentasi. Responden penelitian ditentukan secara purposif, diantaranya pejabat sekolah, guru budang studi, dan guru Bimbingan Konseling. Data dikumpulkan dan disusun kemudian dianalisis dengan menggunakan analisis data kualitatif sebagaimana dikutip dari Sugiyono (2012) yang terdiri dari: (a) reduksi data, (b) display data, dan (c) verifikasi, dimana prosesnya berlangsung secara sirkuler selama penelitian berlangsung. Dalam penelitian ini digunakan uji kredibilitas data dengan cara triangulasi sumber.

\section{HASIL DAN PEMBAHASAN}

\section{Penerapan Pendidikan Karakter dalam Proses Pembelajaran}

\section{a. Sosialisasi Pendidikan Karakter}

Sosialisasi pendidikan karakter bersumber dari pedoman Kementerian Pendidikan Nasional dan hasil workshop yang dilakukan oleh pihak sekolah itu sendiri. Hasilnya kemudian disampaikan kepada para guru untuk dirumuskan secara bersama-sama petunjuk teknis penerapan pendidikan karakter di SMA Negeri 2 Lhokseumawe. Hal itu sebagaimana disampaikan oleh Waka Kurikulum:

"Sejak diberlakukannya K-13 Kepala Sekolah dan beberapa guru yang telah mendapatkan pelatihan membuat sosialisasi khusus di sekolah, agar semua guru paham tentang pembelajaran berbasis karakter yang nantinya menjadi landasan dalam proses belajar mengajar. Pada saat itu sosialisasi yang dilakukan tidak diikuti oleh semua guru bidang 
studi karena waktu yang sangat terbatas. Tapi sebagian besar mengikuti sosialisasi". (Sri Warzukni, S.Si, SMAN 2 Lhokseumawe, 07/01/2020)

Berdasarkan hasil wawancara dengan Waka Kurikulum dapat dipahami bahwa proses sosialisasi yang dilakukan oleh pihak sekolah belum berjalan maksimal sebagaimana yang diharapkan. Waka Kurikulum sudah menyelidiki permasalahan ini dengan berbincang secara tidak formal bersama para guru, ternyata pemahaman guru terhadap arah dan spirit yang diusung oleh kurikulum K-13 masih kurang memadai. Sejumlah guru bidang studi masih kebingungan menafsirkan maksud dan tujuan K-13 ini, apalagi jika harus mengaplikasikan pendidikan karakter ke dalam silabus mata pelajaran. Hal ini membuat penting dan mendesaknya untuk dilakukan sosialisasi secara berkala agar guru sebagai garda terdepan dalam proses pendidikan karakter dapat memahami secara utuh program pemerintah tersebut. Menurut penulis, sekolah perlu segera menangani permasalahan ini.

b. Penyusunan Silabus dan RPP sebagai Turunan dari Kurikulum

Penyusunan Silabus dan RPP menurut keterangan guru bidang studi Pendidikan Agama Islam diwajibkan memasukkan nilai-nilai karakter islami sebagaimana pernyataan berikut:

"Dalam penyusunan RPP kami dituntut untuk menyesuaikan dengan kurikulum terbaru yang dirancang dengan konsep pendidikan karakter. Jadi dalam pembuatan RPP pun kami harus memasukkan nilai-nilai pendidikan karakter meskipun dalam proses penerapannya dirasakan sedikit mengalami kendala, sebab nilai-nilai pendidikan karakter harus benarbenar dipahami dan disesuaikan dengan mata pelajaran yang diasuh. Nilai-nilai tersebut juga harus bernuansa islami.” (Rahmati S.Ag, SMAN 2 Lhokseumawe, 07/01/2020)

Menurut guru bidang studi Sosiologi, dalam proses pembuatan RPP sebagai acuan pembelajaran beliau menerapkan strategi khusus sebagaimana diutarakan:

"Dalam membuat Silabus dan RPP nilai karakter termuat dalam indikator, kalau saya satu indikator nanti termuat beberapa nilai karakter. Nilai karakter yang tertulis dalam RPP tersebut sebisa mungkin akan saya munculkan pada saat proses pembelajaran". (Dra. Suriya, M.M, SMAN 2 Lhokseumawe, 08/01/2020)

\section{c. Pelaksanaan Pendidikan Karakter dalam Pembelajaran}

\section{1) Pembiasaan dan Budaya Sekolah}

Pembiasaan dan perwujudan budaya sekolah sudah dimulai saat siswa hadir di sekolah. Siswa wajib hadir paling tidak 5 (lima) menit sebelum bel masuk berbunyi. Siswa yang terlambat lebih dari 15 menit idealnya mendapatkan sanksi berupa mengutip sampah di pekarangan sekolah dan tidak diperbolehkan mengikuti kegiatan pembelajaran pada jam pertama sesuai dengan 
peraturan yang telah dibuat dalam perencanaan atau telah tertuang dalam tata tertib peraturan sekolah. Namun, dalam praktiknya siswa masih diberikan toleransi 2-3 kali oleh guru mata pelajaran yang bersangkutan dan masih boleh mengikuti jam pelajaran pertama. Hal ini bertentangan dengan harapan Kepala Sekolah:

"Sekolah mentolerir keterlambatan siswa itu sekitar 5 menit setelah bel berbunyi. Saya mengharapkan selalu siswa datang tepat waktu karena di pagi hari begitu siswa sampai di sekolah mereka wajib bersalaman dengan guru-guru dan teman-teman. Jika mereka terlambat maka proses ini tidak akan sempat dilakukan. Namun dalam pelaksanaannya masih ada siswa yang suka terlambat dengan alasan telat bangun. Dan saya juga mengharapkan sekali agar siswa yang terlambat diberikan sanksi oleh guru namun tidak dalam bentuk hukuman fisik." (Nur A'la, S.Pd., MM, SMAN 2 Lhokseumawe, 08/01/2020)

Mengutip sampah adalah bentuk hukuman yang diberikan kepada siswa yang terlambat masuk sekolah. Hukuman ini tidak mengandung unsur kekerasan dan dipandang sebagai salah satu contoh upaya sekolah dalam menciptakan lingkungan yang bersih serta pembudayaan pola hidup bersih dan sehat (PHBS) pada diri siswa sehingga diharapkan terbangun karakter cinta lingkungan dan budaya sekolah yang ramah lingkungan.

Selain itu sekolah mewajibkan seluruh warga sekolah bersalaman setiap pagi sebelum memulai aktivitas pembelajaran di dalam kelas. Para siswa mencium tangan seluruh guru dan bersalaman dengan sesama teman. Hal ini juga sebagai perwujudan nilai-nilai karakter religius pada diri siswa. Selain bersalaman setiap pagi, para siswa juga didorong untuk terbiasa mengucapkan salam dalam menyapa saat mereka bertemu atau berpisah satu sama lain.

Beberapa pembiasaan yang lain diantaranya Upacara Bendera setiap Senin pagi, berdo'a sebelum belajar, sholat dzuhur tepat waktu dan berjama'ah, membaca Yasin setiap Jum'at, mengantri, senam pagi, dan gotong royong. Apabila ada siswa yang melanggar aturan maka pihak guru atau tenaga kependidikan yang berwenang pada saat itu akan melakukan peneguran secara langsung. Para siswa juga didorong memiliki kesadaran untuk melakukan tindakan menegur kawannya yang menyimpang dari aturan sebagai wujud dari nilai religius amar ma'ruf nahi mungkar.

2) Integrasi dalam Pembuatan Silabus dan RPP

Integrasi nilai-nilai karakter dalam mata pelajaran dilakukan dengan cara mengembangkan Silabus dan RPP pada kompetensi yang ada sesuai dengan nilai yang akan diterapkan. Sekolah mendorong para guru untuk berusaha mengintegrasikan antara pendidikan agama dan pendidikan umum. Misalnya dalam mata pelajaran Ekonomi, guru bisa menjelaskan hakikat ekonomi Islam, 
misalnya mengapa Allah SWT mengharamkan riba atau mengharamkan mengurangi takaran dalam kegiatan jual beli atau perdagangan. Begitu juga dalam pelajaran MIPA, guru diminta untuk semakin meningkatkan keimanan siswa dengan mengajak mereka melihat tanda-tanda kebesaran Allah di alam ini.

Menurut salah seorang guru Bimbingan Konseling SMA Negeri 2 Lhokseumawe selaku pelaksana utama pendidikan karakter dan pemantau kegiatan siswa, pendidikan karakter berperan dalam memerangi perilaku menyimpang pada siswa. Pendidikan karakter sebagai landasan yang harus diperhatikan sebelum mengembangkan aspek yang lain sebagaimana petikan wawancara berikut:

"Pelaksanaan pendidikan karakter bertujuan untuk mengurangi perilaku menyimpang siswa, dilakukan oleh semua guru pengajar. Hal itu perlu dilakukan agar semua sisi saling mendukung dan tidak bertolak belakang. Guru setiap bidang studi dalam pengajarannya selalu mencoba mengintegrasikan pendidikan karakrer melalui tema-tema pembelajaran. Jika siswa telah terbentuk karakter dengan benar, maka sisi lain juga akan lebih mudah untuk dibentuk". (Nurjamiati, S.Pd, SMAN 2 Lhokseumawe, 09/01/2020)

3) Keteladanan dan Arahan

Dalam mengatasi perilaku menyimpang siswa di SMA Negeri 2 Lhokseumawe pendidikan karakter dalam proses pembelajaran juga diterapkan melalui kegiatan keteladanan yang merupakan kegiatan yang dapat dilakukan kapan saja dan dimana saja yang lebih mengutamakan pemberian contoh dari guru, Kepala Sekolah, dan pengelola pendidikan lainnya kepada peserta didik. Kegiatan ini bertujuan memberi contoh/keteladanan tentang kebiasaan perilaku yang baik. Guru juga memberi contoh dengan perilaku mengutip sampah yang kebetulan berserakan di depan matanya sehingga murid yang ada di sekitar sekolah juga mengikuti perilaku tersebut dengan membantu sang guru membersihkan lingkungan sekolah.

Kendati demikian, berdasarkan pengamatan peneliti masih sering ditemukan di dalam kelas siswa suka berbohong, menyontek, dan membawa handphone untuk berkomunikasi di tempat yang seharusnya tidak diperbolehkan. Bahkan ada juga siswa yang merokok di tempat tersembunyi seperti di toilet. Hal ini menurut terjadi bukan karena sekolah tidak berbuat apa-apa. Para guru sudah menunjukkan keteladanan dimana mereka tidak pernah merokok di lingkungan sekolah dan tidak asyik bertelepon atau menggunakan handphone pada saat jam pelajaran tengah berlangsung.

Menurut guru Pendidikan Agama Islam, efektivitas pendidikan karakter di SMA Negeri 2 Lhokseumawe khususnya perilaku menyimpang siswa masih belum efektif. Meskipun penerapan pendidikan agama, moral, budaya, dan karakter bangsa telah tercakup dalam proses belajar mengajar, namun penerapan karakter-karakter yang coba ditanamkan tersebut belum begitu 
mampu diaplikasikan ke dalam kehidupan nyata di lingkungan sekolah. Hal ini ditunjukkan dengan masih adanya perilaku negatif yang dilakukan oleh siswa SMA Negeri 2 Lhokseumawe.

Selain masalah atas, dari hasil wawancara dengan beberapa guru bidang studi juga diketahui bahwa selama penerapan pendidikan karakter di SMA Negeri 2 Lhokseumawe belum terlihat perubahan yang berarti di mana siswa yang dari awalnya mempunyai perilaku yang kurang baik, sampai dengan akhir masa belajar di SMA tersebut belum menampakkan perubahan. Terlebih jika tidak ada dukungan dari orang tua, maka akan sangat mustahil penerapan pendidikan karakter akan efektif, karena waktu siswa lebih dari 70 persen berada di luar lingkungan sekolah.

\section{Hambatan Penerapan Pendidikan Karakter dalam Mengatasi Perilaku Menyimpang Siswa}

Kendala pertama datang dari pihak keluarga. Ruang lingkup pendidikan karakter pertama kali tentunya harus ditanam melalui sebuah keluarga. Sebagai wadah dan proses pendidikan pertama bagi seorang anak, keluarga yang pemeran utamanya kedua orang tua memiliki posisi sentral dalam membentuk seorang anak memiliki karakter. Namun dalam kenyataannya tidak semua orang tua paham tentang karakter dan bahkan disibukkan dengan pekerjaan sehingga tidak memiliki waktu untuk memberikan pendidikan dasar bagi anak sebelum anak dititipkan di sekolah. Hal itu berdasarkan pengungkapan Kepala Sekolah yang mengatakan:

"Pendidikan di sekolah merupakan pendidikan lanjutan dari pendidikan keluarga. Rumah merupakan tempat pertama sekali anak-anak dibimbing, dibentuk, dan diarahkan. Jika pondasinya udah kuat maka tidak akan sulit pihak sekolah mengembangkannya. Tapi kebanyakan tidak..." (Nur A'la, S.Pd., M.M, SMAN 2 Lhokseumawe, 08/01/2020)

Terkait pendidikan dasar dalam keluarga, status pendidikan orang tua dan status sosial juga turut mempengaruhi pola asuh yang diterapkan di dalam keluarga. Orang tua yang tidak mengenyam pendidikan tinggi tidak mengetahui pola asuh terbaik bagi anaknya. Sedangkan status sosial orang tua yang rendah memaksa mereka bekerja sepanjang hari sehingga tidak memiliki banyak waktu dalam memperhatikan perkembangan pendidikan anak-anaknya. Pernyataan Kepala Sekolah berikut ini terkait status pendidikan dan status sosial keluarga yang pada akhirnya memberi hambatan bagi proses pendidikan karakter di sekolah sebagaimana disampaikan:

"Banyak orang tua yang belum paham tentang pendidikan karakter bahkan mereka menganggap bahwa pendidikan yang paling utama adalah pendidikan akademik di sekolah. Mencari nafkah lebih mereka prioritaskan daripada datang menghadiri rapat di sekolah jika sekolah mengundang untuk kegiatan sekolah. Memang kalau tidak demikian mereka mau makan apa untuk sehari-hari. Jadi akhirnya bebannya ke kami para guru." (Nur A'la, S.Pd., M.M, SMAN 2 Lhokseumawe, 08/01/2020)

32 Jurnal Ilmu Sosial dan Ilmu Politik Malikussaleh (JSPM) Volume 1 Nomor 1 Periode Januari-Juni 2020 
Penjelasan Kepala Sekolah di atas menyiratkan masyarakat dari kelas bawah sebagian besar tidak memahami betul apa dan bagaimana proses pendidikan karakter dengan menerapkan pola asuh yang baik. Ini terjadi karena masyarakat dari kelas bawah lebih banyak menghabiskan waktu mereka dalam memenuhi roda ekonomi keluarga yang belum mapan sehingga pendidikan karakter bagi anak mereka sedikit terlupakan. Dengan strata sosial seperti ini proses pengenalan pendidikan karakter dalam internal keluarga tidak berjalan sebagaimana mestinya.

Hambatan kedua ialah faktor lingkungan. Lingkungan berperan besar dalam pembentukan karakter seorang anak. Betapapun bagusnya sebuah keluarga dalam mengajarkan pendidikan karakter di rumah namun jika lingkungan anak tersebut tidak mendukung, sudah pasti proses ini akan gagal. Lingkungan dalam hal ini juga termasuk lingkungan pergaulan anak atau kelompok bermain anak. Berdasarkan pengalaman berkecimpung di dalam dunia pendidikan, peneliti menemukan bahwa keluarnya kata-kata kasar dan jorok dari anak-anak saat ini bukan berasal dari pendidikan keluarga, tetapi dari pergaulannya di lingkungan sekitar, khususnya karena meniru teman sepermainan. Guru dan orang tua seringkali dibuat terkejut dengan perilaku buruk siswa atau anak. Padahal sekolah dan keluarga tidak pernah mengajarkan hal demikian.

Hambatan ketiga datang dari kurikulum dan guru/pendidik. Dalam praktiknya di lapangan, pemerintah telah merevisi berkali-kali kurikulum nasional yang menekankan akan pentingnya nilai-nilai karakter diterapkan dalam pembelajaran. Beberapa diantaranya adalah kejujuran, religius, toleransi, disiplin, kerja keras, kreatif, mandiri, dan lain-lain. Namun ditemukan beberapa kendala. Diantara kendala yang dihadapi yaitu kesiapan guru dalam beradaptasi dengan perubahan kurikulum yang dilakukan oleh Kementerian Pendidikan. Gonta-ganti kurikulum yang sering terjadi setiap pergantian pemerintahan membuat para guru bekerja keras untuk menyesuaikan kembali indikator capaian, metode, standar evaluasi, dan sebagainya. Selanjutnya dalam pelaksanaan pendidikan karakter di SMA Negeri 2 Lhokseumawe ada temuan bahwa diantara kalangan guru sendiri belum dilakukan dengan baik dan belum dapat memberikan keteladanan kepada siswa.

Salah seorang guru bidang studi juga mengungkapkan hal yang sama dengan hasil observasi yang dilakukan oleh peneliti. Guru PPKN tersebut menyampaikan keterangan yang berbeda dengan beberapa responden penelitian ini, sebagaimana dikatakan:

"Pendidikan karakter yang baru-baru ini diberlakukan di setiap sekolah masih banyak bertumpu pada teori dan belum benar-benar diaplikasikan ke dalam kehidupan pribadi siswa yang efeknya bisa mengurangi perilaku menyimpang siswa. Walaupun demikian, di SMA Negeri 2 Lhokseumawe ini jarang ditemukan pelanggaran atau perilaku menyimpang

33 Jurnal Ilmu Sosial dan Ilmu Politik Malikussaleh (JSPM) Volume 1 Nomor 1 Periode Januari-Juni 2020 
yang termasuk dalam kategori berat. Namun hanya perilaku menyimpang yang masih dalam batas kewajaran dalam artian masih dapat dimaafkan dan diberi sanksi berupa nasehat atau teguran. Menurut agama fenomena yang demikian juga tidak bisa dibiarkan terus-terusan yang akhirnya memberikan efek yang tidak baik kepada siswa". (Mursyidah. S.Pd, SMAN 2 Lhokseumawe, 10/01/2020)

\section{Pembahasan}

Masyarakat memiliki sebuah elemen yang disebut "fakta sosial". Dalam tingkat mezzo (menengah), norma sebagai fakta sosial juga terdapat di dalam ruang lingkup sekolah. Sekolah adalah miniatur masyarakat dimana norma-norma yang ada di sekolah mencerminkan normanorma yang hidup di tengah masyarakat. Berbagai aturan baik yang bersifat tertulis atau pun tidak tertulis diberlakukan kepada segenap warga sekolah dan memiliki kekuatan memaksa.

Diskusi ini bisa dimulai dengan sebuah pertanyaan: bagaimana tatanan sekolah dicapai dan dipertahankan dan apa tujuan mempertahankan tatanan sekolah? Tatanan sekolah muncul dari norma dan aturan yang dipraktikkan oleh segenap warga sekolah. Norma memungkinkan guru dan siswa untuk beraktivitas di sekolah melalui kesepahaman diantara mereka. Tanpa norma dan aturan, sekolah akan berada dalam kekacauan dan individu yang berinteraksi di dalamnya tidak akan mampu mengendalikan kekacauan tersebut.

Tatanan sekolah terwujud bilamana sekolah berada dalam stabilitas karena konsensus yang mengikatnya. Tatanan sekolah hadir ketika seluruh guru dan siswa "menyetujui" kontrak sosial bersama dimana nilai dan norma tertentu dipertahankan dan aturan ditegakkan. Dengan demikian, adanya nilai, keyakinan, praktik, dan perilaku yang bertentangan dengan tatanan sekolah akan dianggap menyimpang bahkan berbahaya sehingga dibatasi melalui penegakan aturan, norma, dan tabu.

Tatanan sekolah pada umumnya bersifat hierarkis. Dalam hal ini, beberapa orang memegang kekuasaan lebih dari yang lain sehingga mereka dapat menegakkan aturan dan norma yang diperlukan untuk pelestarian tatanan sekolah. Mereka adalah Kepala Sekolah dan para guru yang memainkan peran formatif dalam mengembangkan kesadaran kolektif seluruh siswa. Maka mereka juga disebut sebagai figur otoritas di lingkungan sekolah. Melalui interaksi dengan figur otoritas siswa berpartisipasi dalam pemeliharaan aturan dan norma serta perilaku yang memungkinkan kelancaran fungsi belajar mengajar di sekolah. Ketertiban di sekolah muncul ketika ada kerjasama yang baik diantara seluruh warga sekolah.

Sekolah adalah wadah yang akan menghubungkan individu dengan masyarakat. Sekolah membantu dalam mengatur individu dan mengintegrasikan individu ke dalam masyarakat. Proses

34 | Jurnal Ilmu Sosial dan Ilmu Politik Malikussaleh (JSPM) Volume 1 Nomor 1 Periode Januari-Juni 2020 
sosialisasi berpedoman pada norma dan diajarkan kepada anak didik oleh figur otoritas di sekitarnya, termasuk juga dalam hal ini keluarga, guru, dan tokoh agama. Seorang anak mempelajari norma tidak hanya melalui arahan lisan dan tertulis, tetapi juga dengan mengamati orang-orang di sekitarnya. Mempelajari norma-norma di sekolah dan di dalam kelompok masyarakat memungkinkan anak tersebut berfungsi secara sosial dalam sistem masyarakat tersebut dan pada akhirnya diterima sebagai bagian dari kelompok atau masyarakat.

Aturan sekolah merupakan representasi dari norma-norma masyarakat di lingkungan sekolah tersebut. Sebab sekolah adalah salah satu agen masyarakat. Apabila ada siswa yang melanggar aturan, ia secara sosial akan dicap menyimpang, maka siswa itu pun akan menerima sanksi dari figur otoritas di sekolah tersebut. Pelabelan menyimpang dan penerapan sanksi bagi pelaku penyimpangan menegaskan bahwa nilai-nilai dan norma-norma itu memang nyata adanya.

Sebagian besar siswa pada dasarnya menyadari keberadaan norma yang berada di luar dirinya yang bersifat "memaksa" ini sehingga mereka tahu caranya menyesuaikan perilaku sesuai dengan arahan norma tersebut. Selain itu, mereka juga menilai perilaku sesama siswa yang lain sesuai dengan norma-norma yang dianut. Dengan demikian, norma lebih sering ditegakkan dengan cara yang tidak disadari. Menurut penulis, setiap siswa bisa merasakan bahwa perilakunya diperbolehkan atau tidak diperbolehkan oleh norma, sehingga kebanyakan dari siswa mematuhi aturan-aturan di sekolah. Kekuatan peraturan di sekolah sesungguhnya berasal dari ekspektasi orang lain, diantaranya ekspektasi guru dan sesama siswa terhadap siswa lain. Adanya ancaman dipermalukan, diberi sanksi, atau dikucilkan karena tidak mematuhi peraturan, memaksa siswa untuk senantiasa mengingat dampak yang ditimbulkan dari pelanggaran yang dilakukannya. Norma pada akhirnya merupakan kekuatan moral yang mampu menahan ego setiap siswa untuk berbuat semaunya atau berbuat tidak sesuai dengan aturan sekolah.

Norma sekolah memandu perilaku siswa. Ketika perilaku seorang siswa rusak, norma sekolah meminta reaksi orang lain (guru dan teman siswa) untuk menegaskan keberadaannya. Guru mungkin memberikan sanksi terhadap perilaku siswa secara visual dengan kontak mata dan ekspresi wajah, atau secara lisan, atau memberikan hukuman secara langsung yang diharapkan dapat meninggalkan kesan atau efek jera. Sementara teman-teman siswa menjauhi, menggunjing, atau menertawakannya. Hal ini sebagai salah satu bentuk sanksi sosial. Keadaan tersebut membentuk kekuatan moral bersama yang mampu mempertahankan sentimen semangat solidaritas dalam kesadaran semua siswa. Demikianlah kontribusi positif yang dapat diberikan oleh institusi pendidikan dalam pemeliharaan sistem sosial.

35 | Jurnal Ilmu Sosial dan Ilmu Politik Malikussaleh (JSPM) Volume 1 Nomor 1 Periode Januari-Juni 2020 
Kendati demikian, pelanggaran terhadap aturan dan norma baik di lingkungan sekolah maupun di luar lingkungan sekolah masih kerapkali terjadi. Pihak sekolah dalam hal ini bertindak dalam rangka melindungi institusi dari berbagai "disfungsi" yang mungkin dilakukan oleh sebagian warga sekolah. Namun bila dilihat lebih dekat, istilah disfungsi itu sendiri sebenarnya mengandung masalah, sarat dengan kepentingan kelompok tertentu, dan terlalu mengeneralisasi pendefinisian. Disfungsi yang terjadi di dalam tubuh institusi pendidikan ini kiranya perlu diidentifikasi lebih jauh dengan melihat sudut pandang siswa yang "dituduh" melakukan penyimpangan. Peneliti menggali permasalahan siswa dalam sejumlah percakapan informal dengan beberapa siswa di SMA Negeri 2 Lhokseumawe dengan hasil temuan sebagaimana terangkum dalam Tabel 2.

Tabel 2. Sudut Pandang Pelaku Konformitas dan Penyimpangan

\begin{tabular}{|c|c|c|c|}
\hline No & $\begin{array}{c}\text { Pola Adaptasi } \\
\text { Siswa }\end{array}$ & $\begin{array}{c}\text { Fenomena yang } \\
\text { Mencuat }\end{array}$ & Alasan Pelaku \\
\hline 1 & Conformity & $\begin{array}{l}\text { Tekun belajar, jujur, } \\
\text { religius, tanggung } \\
\text { jawab, dan lain-lain }\end{array}$ & $\begin{array}{ll}\text { - } & \text { Harapan dan doa orang tua } \\
\text { - } & \text { Kesadaran siswa demi meraih cita-cita } \\
\text { - } & \text { Nasehat guru pasti untuk kebaikan } \\
\text { - } & \text { Belajar sudah membudaya di dalam diri } \\
\end{array}$ \\
\hline 2 & Innovation & Menyontek & $\begin{array}{ll}\text { - } & \text { Lupa belajar } \\
\text { - } & \text { Tidak memahami materi pelajaran karena } \\
\text { masalah metode mengajar guru yang } \\
\text { membosankan } \\
\text { - } \\
\text { Tidak suka dengan suatu mata pelajaran } \\
\text { tetapi terpaksa harus mempelajari semuanya }\end{array}$ \\
\hline 3 & Ritualism & $\begin{array}{l}\text { Tidak tahu tujuan } \\
\text { menempuh pendidikan }\end{array}$ & $\begin{array}{l}\text { - Sekolah karena dipaksa orang tua } \\
\text { - } \\
\text { Sekolah karena teman-teman semua pergi ke } \\
\text { sekolah } \\
\text { - } \quad \text { Lebih baik ke sekolah daripada cuma } \\
\text { bengong di rumah }\end{array}$ \\
\hline \multirow[t]{4}{*}{4} & \multirow[t]{4}{*}{ Retreatism } & $\begin{array}{l}\text { Membuang sampah } \\
\text { sembarangan }\end{array}$ & 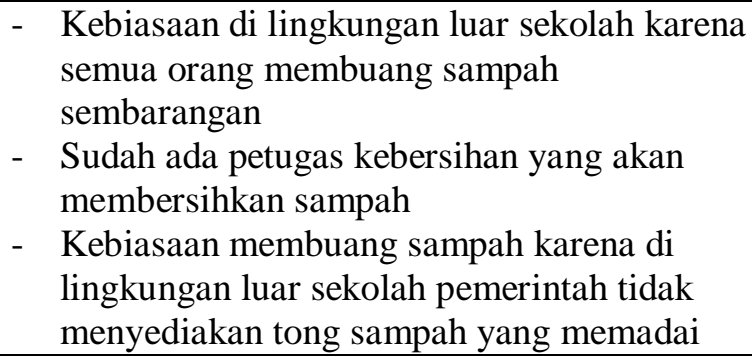 \\
\hline & & Membolos & $\begin{array}{ll}\text { - } & \text { Guru yang mengajar tidak menarik } \\
\text { - } & \text { Dipengaruhi teman } \\
\text { - } & \text { Takut dikucilkan dalam pergaulan } \\
\end{array}$ \\
\hline & & Merokok & $\begin{array}{ll}\text { - } & \text { Dipengaruhi teman } \\
\text { - } & \text { Takut dikucilkan dalam pergaulan kelompok } \\
\text { - } & \text { Orang tua kok boleh merokok } \\
\text { - } & \text { Merokok itu keren }\end{array}$ \\
\hline & & $\begin{array}{l}\text { Menyalahgunakan } \\
\text { narkoba }\end{array}$ & $\begin{array}{ll}\text { - } & \text { Broken home } \\
\text { - } & \text { Dipengaruhi teman } \\
\text { - } & \text { Sudah kecanduan } \\
\end{array}$ \\
\hline
\end{tabular}

36 | Jurnal Ilmu Sosial dan Ilmu Politik Malikussaleh (JSPM) Volume 1 Nomor 1 Periode Januari-Juni 2020 


\begin{tabular}{|c|c|c|c|}
\hline & & Pacaran & $\begin{array}{l}\text { - } \quad \text { Sudah jadi trend anak muda saat ini } \\
\text { - Pengaruh media } \\
\text { - } \quad \text { Malu kalau dibilang jomblo atau "gak laku" }\end{array}$ \\
\hline & & $\begin{array}{l}\text { Berkata kasar dan } \\
\text { bercakap kotor }\end{array}$ & $\begin{array}{l}\text { - Pengaruh lingkungan } \\
\text { - Pengaruh peer group } \\
\text { - } \text { Pengaruh media }\end{array}$ \\
\hline 5 & Rebellion & $\begin{array}{l}\text { Sejauh ini tidak ada } \\
\text { gejala siswa terpapar } \\
\text { radikalisme atau hal- } \\
\text { hal lain yang } \\
\text { mengarah ke arah sana }\end{array}$ & \\
\hline
\end{tabular}

Memperhatikan kembali beberapa motif siswa pelaku penyimpangan di atas dapat dimengerti bahwa tidak semua tindakan menyimpang lahir murni sebagai wujud dari karakter siswa yang buruk. Terdapat konteks situasi yang mendorong lahirnya penyimpangan. Penulis mengambil contoh menyontek sebagai perilaku menyimpang (pola adaptasi innovation) yang berdasarkan laporan guru merupakan masalah paling banyak terjadi di SMA Negeri 2 Lhokseumawe. Bila dikaitkan dalam pembahasan pendidikan karakter, realitasnya siswa yang menyontek tersebut cenderung diberi label oleh gurunya sebagai siswa malas. Tetapi apakah semua siswa yang menyontek itu benar-benar siswa yang malas dan dengan demikian disebut siswa menyimpang atau disfungsi? Ataukah jangan-jangan institusi pendidikan yang menerapkan nilai dan norma itu sendiri juga sedang mengalami disfungsi?

Bila memahami alasan siswa menyontek karena tidak mengerti dengan materi pelajaran yang dijelaskan oleh guru, hal ini berarti ada yang salah dalam metode pengajaran yang diterapkan oleh guru. Atau bahkan mungkin ada masalah dalam sistem pendidikan di Indonesia pada umumnya. Beberapa guru memang harus dimaklumi, berdasarkan amatan peneliti, tidak memiliki kemampuan yang baik dalam mengajar. Secara makro, institusi pendidikan yang melahirkan guru, misalnya universitas, seharusnya juga ikut bertanggung jawab atas situasi ini yang menyebabkan terjadinya disfungsi dalam sistem belajar mengajar di sekolah. Mengapa ada guru yang tidak bisa mengajar tetapi bisa lulus menjadi seorang guru?

Begitu pula halnya dengan kurikulum dan mata pelajaran yang ditetapkan oleh pemerintah pusat, apakah sudah benar-benar mengakomodasi bakat dan minat para siswa? Ataukah pendidikan yang dijalani selama ini terlalu bersifat umum, menyamaratakan, dan cenderung hanya mempersiapkan siswa sebagai "calon tenaga kerja" atau "calon buruh" untuk mendukung berjalannya institusi ekonomi? Ditambah lagi dengan fenomena kurikulum yang dibuat terlalu prosedural sehingga guru pada akhirnya berupaya mengejar ketercapaian penyampaian materi pelajaran beserta indikator-indikatornya yang tertuang di dalam Silabus tanpa memperhatikan 37 | Jurnal Ilmu Sosial dan Ilmu Politik Malikussaleh (JSPM) Volume 1 Nomor 1 Periode Januari-Juni 2020 
apakah seluruh siswa benar-benar sudah menyerap materi pelajaran yang sudah diberikan sebelumnya.

Di sisi lain, sekolah tidak mengklasifikasikan pola adaptasi ritualism sebagai tindakan menyimpang siswa. Siswa yang biasa-biasa saja ini memang cenderung patuh terhadap semua aturan di sekolah dan jarang berbuat keonaran. Tetapi bila benar-benar ditanyakan dan ditelusuri motif mereka ke sekolah, tidak diperoleh keterangan yang jelas. Para siswa hanya menjalani rutinitas di sekolah karena memang lingkungan sosial sudah merancang sedemikian adanya. Pendidikan formal sudah menjadi institusi yang diterima keberadaannya oleh seluruh lapisan masyarakat sehingga tidak mungkin ada anak yang mampu menolak disuruh pergi ke sekolah. Ia pasti akan "dipaksa” ke sekolah. Namun karena siswa yang mengambil pola adaptasi ritualism jarang berbuat keonaran atau berbuat masalah di sekolah, mereka tidak dilabel menyimpang, meskipun sesungguhnya kelompok siswa ini tidak memahami tujuan kebudayaan yang diharapkan ada pada diri mereka.

Tabel 3.

Tindakan Pihak Sekolah terhadap Perilaku Menyimpang

\begin{tabular}{|c|l|c|l|}
\hline No & $\begin{array}{c}\text { Pola Adaptasi } \\
\text { Siswa }\end{array}$ & $\begin{array}{c}\text { Identifikasi Pihak } \\
\text { Sekolah }\end{array}$ & \multicolumn{1}{|c|}{ Tindakan Guru/Pihak Sekolah } \\
\hline 1 & Conformity & Tidak menyimpang & $\begin{array}{l}\text { Perilaku para siswa kelompok ini adalah yang } \\
\text { diharapkan oleh sekolah dan masyarakat pada } \\
\text { umumnya sehingga diberi hadiah dan apresiasi. }\end{array}$ \\
\hline 2 & Innovation & Menyimpang & $\begin{array}{l}\text { Menegur, menasehati, memarahi, memasang } \\
\text { raut muka tidak suka, menghukum, memberi } \\
\text { nilai jelek, tidak diluluskan. }\end{array}$ \\
\hline 3 & Ritualism & Tidak menyimpang & $\begin{array}{l}\text { Umumnya siswa kategori ini tidak dilabel oleh } \\
\text { sekolah sebagai perilaku menyimpang. Hal ini } \\
\text { karena para siswa sudah memenuhi minimal } \\
\text { prosedur administrasi sekolah dan formalitas } \\
\text { dalam proses pendidikan. }\end{array}$ \\
\hline 4 & Retreatism & Menyimpang & $\begin{array}{l}\text { Menegur, menasehati, memarahi, menghukum, } \\
\text { memberi nilai jelek, menyurati orang tua, tidak } \\
\text { diluluskan, menghadap guru BK, mengeluarkan } \\
\text { dari sekolah. }\end{array}$ \\
\hline 5 & Rebellion & Menyimpang & $\begin{array}{l}\text { Kasus belum ada namun sekolah tetap } \\
\text { melakukan upaya preventif karena dewasa ini } \\
\text { program pemerintah yang terkait dengan } \\
\text { pencegahan radikalisasi begitu masif. }\end{array}$ \\
\hline
\end{tabular}

Menurut peneliti, fenomena penyimpangan sosial yang mencuat beserta permasalahan yang melatarbelakanginya mungkin luput dari pemahaman pihak sekolah sehingga dibuat program dan 
kegiatan pendidikan karakter yang tidak semuanya menyentuh akar permasalahan di tingkat siswa. Jadi dapat dikatakan bahwa program pendidikan karakter cenderung hanya mengarahkan targetnya kepada siswa atau individu. Program ini tidak menjangkau permasalahan yang bersifat sistemik seperti yang sudah penulis uraikan sebelumnya. Maka tidak mengherankan bila temuan lapangan dari hasil pandangan subjektif para informan menilai program pendidikan karakter belum mampu secara efektif mengatasi perilaku menyimpang seluruh siswa, terutama sekali perilaku siswa yang suka menyontek di setiap pelaksanaan ujian.

Menurut penulis, permasalahan siswa bukan hanya terletak pada aspek karakter yang buruk sehingga mereka menyontek. Tapi ada kondisi dimana mereka tidak menguasai materi sehingga dalam mencapai tujuan budaya untuk "lulus ujian" mereka terpaksa menggunakan cara-cara di luar ketentuan institusi yang sah. Sementara program pendidikan karakter yang diterapkan oleh sekolah tidak menjawab permasalahan ini.

Bila diilustrasikan, harapan pihak sekolah melalui penerapan program pendidikan karakter di SMA Negeri 2 Lhokseumawe sebagai berikut:

\section{Bagan 2.}

Skema Program Pendidikan Karakter di SMA Negeri 2 Lhokseumawe
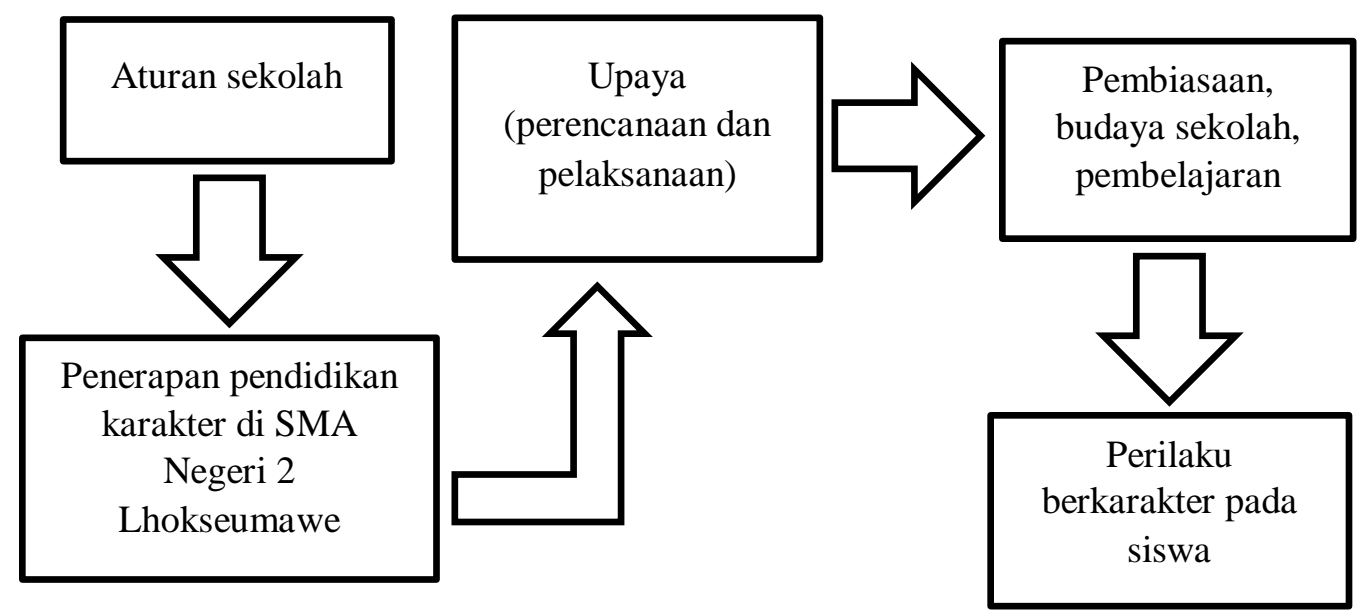

Ilustrasi bagan yang ditampilkan di atas memberi sinyal bahwa program pendidikan karakter ini merupakan kebijakan pendidikan yang dirumuskan secara top-down (dirumuskan dari atas ke bawah) tanpa melibatkan siswa, minimal dengan bertanya permasalahan mendasar yang dialami oleh siswa sehingga berperilaku menyimpang. Pendekatan semacam ini mengabaikan konteks situasi penyebab perilaku menyimpang dengan langsung memvonis tindakan menyimpang 
pada diri individu yang salah. Karena salah, perilaku individu harus diubah ke arah yang benar. Tetapi tanpa mengubah sistem yang salah, apakah individu akan mampu berubah dari perilaku salah?

Masalahnya bila siswa yang tidak mengerti materi pelajaran tidak menyontek maka ia terancam tidak akan lulus ujian. Banyaknya siswa yang tidak lulus ujian pada akhirnya juga menjadi masalah di dalam sekolah yang dapat mencoreng nama baik sekolah di mata Dinas Pendidikan. Kadangkala terjadinya kebocoran soal ujian nasional juga diinisiasi oleh beberapa oknum figur otoritas di dalam sekolah sehingga hal ini juga menambah buruk situasi pendidikan karakter yang sesungguhnya karena terjadi keadaan anomie. Para siswa kebingungan dengan situasi dimana sekolah mengajarkan pentingnya kejujuran, tapi pada situasi tertentu ada oknum guru atas nama sekolah yang mendorong terjadinya tindakan menyontek kunci jawaban pada saat ujian nasional berlangsung dan informasi ini sampai pula kepada siswa-siswa yang lebih junior. Jadi dimana letak keteladanan guru dalam kasus ini?

Sejauh ini, sekolah tampaknya terlalu memaksakan pengkaitan konsep antara variabel pendidikan karakter dan variabel perilaku menyimpang. Secara pemahaman konsep sangat tidak mungkin program pendidikan karakter akan mampu menangani semua bentuk perilaku menyimpang. Apalagi kegiatan-kegiatan yang dilakukan cenderung mendukung status quo, konservatif, prosedural, dan abai terhadap disfungsi di tingkat sistem.

Selama ini sekolah menerapkan pendisiplinan tubuh pada diri siswa. Siswa diatur jam masuk sekolah, seragam yang harus dikenakan, indikator kerapian, apa yang harus dipelajari, harus mengerjakan tugas-tugas dari guru, dan seterusnya. Bila aturan dilanggar, sanksi akan diberlakukan. Beberapa sanksi yang diterapkan misalnya mengutip sampah, menghafal ayat-ayat pendek, dan sebagainya. Seluruh aktivitas ini dibingkai dalam istilah yang dinamakan penciptaan budaya sekolah yang mendukung pendidikan karakter. Sebuah upaya pembudayaan atau pendisiplinan. Beberapa aktivitas lainnya yaitu mengantri dan mengikuti upacara bendera tetapi sering terjadi tanpa penghayatan. Dalam kaitannya dengan aspek religiusitas beberapa kegiatan yang dibudayakan seperti mengucap salam, berdoa, sholat berjamaah, mengaji surat Yasin, ceramah, pesantren kilat, dan kegiatan yang menunjang sisi ruhiyah. Hal ini sebenarnya sangat diperlukan dan tidak menjadi permasalahan. Tetapi menurut penulis, masih ada satu hal yang kurang atau terlewatkan dalam rangkaian proyek sosial tersebut. Suatu hal yang tidak mencuat ialah tidak terjadinya proses dialog yang setara, yang tidak terdistorsi, dan mencerahkan. Suatu upaya mengembalikan siswa kepada hakikat kemanusiaannya. Pendidikan yang memanusiakan manusia, bukan malah membuat siswa seperti robot yang dikendalikan sedemikian rupa. Aspek 
pencerahan ini belum benar-benar berjalan dalam sistem pendidikan di SMA Negeri 2 Lhokseumawe. Keadaan ini membuat aturan dijalankan lebih karena ketakutan atas sanksi yang dapat diterima kalau melanggar ketimpang kesadaran internal siswa untuk menegakkan aturan. Diperparah lagi, seperti yang sudah disampaikan sebelumnya, masalah siswa tidak terakomodasi dengan baik sehingga mereka terpaksa menyimpang.

Ketika program pendidikan karakter digaungkan, aktivitas yang dilakukan oleh perumus dan pelaksana kebijakan kembali terjebak dalam nuansa birokratis dan prosedural. Menyusun RPP dan Silabus, tapi tidak ada jaminan dalam penerapannya di lapangan karena satu dan lain hal. Sementara proses pengendalian sosial dilakukan dengan cara menegur dan mengingatkan, atau sistem muzakarah. Hal ini tampaknya hanya dijalankan oleh guru, sementara di tingkat siswa masih ada keengganan untuk menjalankannya. Sementara cara persuasif yang diterapkan oleh guru walaupun dalam spirit hukuman non kekerasan, dalam amatan peneliti ada beberapa kasus dimana guru justru menerapkan bentuk kekerasan verbal.

Beberapa pembudayaan sekolah yang lain seperti gotong royong, operasi semut, dan piket kelas juga tidak dilakukan oleh siswa benar-benar karena dorongan kesadarannya, tetapi karena takut mendapatkan sanksi dari figur otoritas. Hal ini seolah berantitesa dengan slogan-slogan yang ditempelkan di seputaran lingkungan sekolah yang kosong tanpa makna.

\section{KESIMPULAN}

Setelah mengkaji permasalahan dan temuan data lapangan di atas, peneliti dapat memahami bahwa penerapan pendidikan karakter di SMA Negeri 2 Lhoksemawe dilakukan melalui beberapa strategi, diantaranya: a). Pemberian sosialisasi kepada guru tentang program pendidikan karakter yang bertujuan untuk menyamakan persepsi diantara para pendidik di lingkungan SMA Negeri 2 Lhoksemawe; b). Penyusunan Silabus dan RPP yang berbasis pendidikan karakter yang dituangkan dalam indikator capaian pembelajaran; c). Pengintegrasian dan penerapan nilai-nilai yang berkaitan dengan pendidikan karakter dalam proses belajar mengajar di kelas; d) Penciptaan budaya sekolah yang mendukung proses pendidikan karakter; e) Pembiasaan siswa untuk berperilaku sesuai dengan harapan sistem; dan f) Keteladanan guru.

Penerapan pendidikan karakter dalam rangka mengurangi perilaku menyimpang siswa belum berjalan optimal karena menghadapi sejumlah kendala, seperti a) Minimnya kontribusi keluarga dalam mendidik anak dan tidak adanya pondasi pendidikan karakter yang kuat dari keluarga; b) Inkonsistensi nilai dan norma sekolah dengan nilai dan norma di lingkungan luar sekolah, terutama dalam kelompok bermain siswa; dan c) Kurikulum pendidikan yang mudah 
berganti dan kurangnya pemahaman guru dalam menerapkan dan mengaplikasikan nilai-nilai karakter ke dalam pelajaran. Selain itu, dan mungkin sangat krusial sifatnya, pendefinisian perilaku menyimpang dan disfungsi sosial selama ini hanya bertumpu pada "menyalahkan perilaku individu yang menyimpang", tetapi menutup mata pada masalah pendidikan yang bersifat sistemik yang pada akhirnya mendorong siswa ke arah perilaku menyimpang dan keadaan anomie.

Berdasarkan hasil penelitian, pembahasan, dan simpulan yang telah diuraikan oleh peneliti di atas, maka beberapa rekomendasi yang dapat diberikan kepada SMA Negeri 2 Lhoksemawe sebagai berikut:

1. Sekolah perlu melakukan kajian mendalam dan menyeluruh mengenai penyebab perilaku menyimpang pada siswa dari perspektif siswa sendiri. Dengan demikian, dapat dipetakan masalah yang sebenarnya karena ada upaya untuk mendengarkan suara-suara yang terpinggirkan selama ini di dalam institusi pendidikan. Dalam hal ini, guru Bimbingan Konseling dapat diberdayakan sebagai ujung tombak dalam menggali dan memahami masalah-masalah yang dialami siswa dan perlu dijauhkan adanya kesan untuk menghukum siswa.

2. Sekolah perlu membangun hubungan kerjasama dengan masyarakat dan keluarga dalam rangka mendukung pelaksanaan kegiatan pendidikan karakter dan pengontrolan perilaku siswa di luar jam sekolah.

3. Sekolah perlu mengobati penyakit di dalam institusi pendidikan yang sifatnya sistemik dan disfungsional seperti masalah guru yang tidak mampu dan tidak menarik dalam mengajar melalui kebijakan Kepala Sekolah, program, dan kegiatan yang mampu mengeksekusi dan mengatasi permasalahan tersebut langsung di tingkat sekolah.

\section{DAFTAR PUSTAKA}

Aceh.tribunnews.com (15/02/2013). Pelajar Lhokseumawe Terlibat Pergaulan Bebas. Diakses 5 Februari 2020. https://aceh.tribunnews.com/2013/ 02/15/70-pelajar-lhokseumaweterlibat-pergaulan-bebas

Aceh.tribunnews.com (22/06/2016). Pemuda Tawuran di Terminal 1 Luka. Diakses 5 Februari 2020. https://aceh.tribunnews.com/amp/2016/06/22/pemuda-tawuran-di-terminal-1-luka

Aceh.tribunnews.com (10/04/2019). Ini Jumlah HIV/AIDS yang Ditemukan di Lhokseumawe Pada Tahun Ini. Diakses 5 Februari 2020. https://aceh.tribunnews.com/2019/04/10/inijumlah-kasus-hivaids-yang-ditemukan-di-lhokseumawe-pada-tahun-ini

42 Jurnal Ilmu Sosial dan Ilmu Politik Malikussaleh (JSPM) Volume 1 Nomor 1 Periode Januari-Juni 2020 
Acehportal.com (28/04/2020). Ratusan Remaja Balap Liar di Jalan Len Pipa Aceh Utara $\begin{array}{lllll}\text { Ditangkap } & \text { Polisi. } & \text { Diakses } & 30 & \text { April }\end{array}$ https://www.acehportal.com/2020/04/28/ratusan-remaja-balap-liar-di-jalan-len-pipaaceh-utara-ditangkap-polisi/

Bahri, S. (2015). Implementasi Pendidikan Karakter dalam Mengatasi Krisis Moral di Sekolah. Ta'allum, 3(1), 57-76.

Citra, Y. (2012). Pelaksanaan Pendidikan Karakter dalam Pembelajaran. E-JUPEKhu: Jurnal Ilmiah Pendidikan Khusus, 1(1), 237-249.

Erianjoni (2015). Pelabelan Orang Minangkabau pada Pelaku Penyimpangan Sosial: Studi Kasus pada Dua Nagari di Sumatera Barat. Humanus, 14(1), 31-39.

Harianrakyataceh.com (02/09/2016). LGBT Mulai Marak di Lhokseumawe. Diakses 4 Maret 2020. https://harianrakyataceh.com/2016/09/02/lgbt-mulai-marak-di-lhokseumawe/

Hendriana, E. C. \& Jacobus, A. (2016). Implementasi Pendidikan Karakter di Sekolah Melalui Keteladanan dan Pembiasaan. Jurnal Pendidikan Dasar Indonesia 1(2), 25-29.

Henslin, J. M. (2017). Sociology: A Down-to-Earth Approach. Pearson Education.

Herabudin (2015). Pengantar Sosiologi. Pustaka Setia.

Kanalaceh.com (17/11/2017). Terlibat Narkoba 4 Remaja Lhokseumawe Dibekuk. Diakses 4 Maret 2020. https://www.kanalaceh.com/2017/ 11/17/terlibat-narkoba-4-remajalhokseumawe-dibekuk/

Kementerian Pendidikan Nasional Republik Indonesia. (2011). Panduan Pelaksanaan Pendidikan Karakter. Badan Litbang Pusat Kurikulum dan Perbukuan Kemendiknas.

Juwita, R, et. al. (2020). Meta Analisis: Perkembangan Teori Struktural Fungsional dalam Sosiologi Pendidikan. Jurnal Perspektif: Jurnal Kajian Sosiologi dan Pendidikan, 3(1), $1-8$.

Maunah, B. (2015). Implementasi Pendidikan Karakter dalam Pembentukan Kepribadian Holistik Siswa. Jurnal Pendidikan Karakter, 5(1), 90-101.

Moleong, L. J. (2010). Metodologi Penelitian Kualitatif. Remaja Rosdakarya.

Mulyadi, L. (2009). Kajian Kritis dan Analitis terhadap Dimensi Teori-Teori Kriminologi dalam Perspektif Ilmu Pengetahuan Hukum Pidana Modern. Jurnal Hukum, 5(6), 1-29.

Narwoko, J. D. \& Suyanto, B. (2007). Sosiologi Teks Pengantar dan Terapan. Kencana.

Risdawati (2014). Upaya Bimbingan Konseling Islam dalam Mengatasi Perilaku Menyimpang. Hikmah, 8(2), 74-87.

Ritzer, G. \& Goodman, D. J. (2011). Teori Sosiologi: Dari Teori Sosiologi Klasik Sampai Perkembangan Mutakhir Teori Sosial Postmodern. Kreasi Wacana.

Salmiah (2017). Peran Sekolah sebagai Agen Sosialisasi dalam Pembentukan Moral Siswa di MAN 3 Makassar. Jurnal Sosialisasi, 4(1), 98-103.

43 | Jurnal Ilmu Sosial dan Ilmu Politik Malikussaleh (JSPM) Volume 1 Nomor 1 Periode Januari-Juni 2020 
Setiadi, E. M. \& Kolip, U. (2011). Pengantar Sosiologi Pemahaman Fakta dan Gejala Permasalahan Sosial: Teori, Aplikasi, dan Pemecahannya. Kencana.

Setiawati, N. A. (2017). Pendidikan Karakter sebagai Pilar Pembentukan Karakter Bangsa. Proseding Seminar Nasional Tahunan FIS Unimed, Tahun 2017 Volume 1 Nomor 1.

Sidi, P. (2014). Krisis Karakter dalam Perspektif Teori Struktural Fungsional. Jurnal Pembangunan Pendidikan: Fondasi dan Aplikasi, 2(1), 72-81.

Sugiyono (2012). Memahami Penelitian Kualitatif. Alfabeta.

Sunarto, K. (2004). Pengantar Sosiologi (Edisi Revisi). Lembaga Penerbit Fakultas Ekonomi Universitas Indonesia.

Tandi, S. (2019). Educational Contribution of Emile Durkheim: a Functional Assessment. The Research Journal of Social Sciences, 10(2), 146-156.

Upe, A. (2010). Tradisi Aliran dalam Sosiologi: Dari Filosofi Positivistik ke Post Positivistik. Rajawali Pers.

Xena, A. (2019). Internalisasi Pendidikan Karakter di Pondok Pesantren. Dewantara, 7(1), 90-103. 